\title{
Agriculture and Rural Development as a Main Objective of Polish Cooperation and Development Aid for the Republic of Moldova
}

\author{
Rolnictwo i rozwój obszarów wiejskich jako główny cel polskiej współpracy \\ i pomocy rozwojowej na rzecz Republiki Mołdawii
}

\section{- Abstract •}

Agriculture and development of rural areas are important sectors of Polish-Moldovan cooperation and development aid. Importantly, both of them constitute structural problems, similar to those which faced agriculture in Poland in the 1990s. Through Polish aid and development cooperation, various measures are initiated which increase the competitiveness of Moldovan agricultural production, improve sanitary and phytosanitary conditions, bring technological innovations in agricultural farms, ensure modernization of rural infrastructure, providing support to small and medium-sized entrepreneurs, cooperatives, and agricultural consultants, along with professional activation of the Republic's residents.

Keywords: Republic of Moldova; Eastern Partnership; Polish-Moldovan economic co-operation; Policy Coherence for Development; Policy Coherence for Development of the European Union; Polish Official Development Aid; Polish Aid; agriculture; rural development; projects; small grants

\section{- Abstrakt •}

Rolnictwo i rozwój obszarów wiejskich to ważny sektor polsko-mołdawskiej współpracy i pomocy rozwojowej. Co istotne - są to problemy strukturalne, podobne do tych, z jakimi borykało się jeszcze w latach 90. XX w. rolnictwo w Polsce. Poprzez polską pomoc i współpracę rozwojową inicjowane są działania zwiększające konkurencyjność mołdawskiej produkcji rolnej, usprawniające warunki sanitarne i fitosanitarne, wdrażające innowacje technologiczne w gospodarstwach rolnych, zapewniające modernizację infrastruktury wiejskiej, wspierające małą i średnią przedsiębiorczość, spółdzielczość oraz doradztwo rolnicze, a także aktywizację zawodową mieszkańców Republiki.

Słowa kluczowe: Republika Mołdawii; partnerstwo wschodnie; polsko-mołdawska współpraca gospodarcza; spójność polityki na rzecz rozwoju; spójna polityka na rzecz rozwoju Unii Europejskiej; polska oficjalna pomoc rozwojowa; polska pomoc rozwojowa; rolnictwo; rozwój obszarów wiejskich; projekty; małe granty 


\section{Introduction}

Poland (PL) and the Republic of Moldova (RM) have strong historical ties, dating back to the $14^{\text {th }}$ century. Nonetheless, their history, notably the influence of relations with Turkey, Romania, Russia, and finally the Soviet Union allowed renewed cooperation between these countries only after 1991, when Poland recognized the sovereignty of the Republic. In 1992, it established diplomatic relations with Moldova and signed the first document related to trade and economic cooperation. In 1994, Poland and Moldova concluded the "Treaty between the Republic of Poland and the Republic of Moldova on Friendship and Cooperation", which formed the basis of Polish-Moldovan relations; it entered into force in 1996. In that year the Polish embassy in Chisinau was opened (Kosienkowski, 2012, p. 92; Goworko-Składanek, 2015, p. 238). Also important were Polish economic relations established with the separatist region of Transnistria, initiated to some extent with the consent of the central authorities in Chisinau. As early as the beginning of the 1990s, Poland became one of the main economic partners of the Transnistrian region (import of food and construction products from PL to the $\mathrm{RM})$, contributing, among other things, to building the power of the regional corporate holding Sheriff (Kosienkowski, 2012, pp. 105-106; Wróbel, 2012, p. 37) ${ }^{1}$. In 1997 a Moldovan outpost was opened in Warsaw (Kosienkowski, 2012, p. 92). In the following years other areas of cooperation were also initiated (Goworko-Składanek, 2015, p. 238)2.

However, a breakthrough in Polish-Moldovan relations can only be said to have occurred after 2004, when Poland became a member of the Europe-

${ }^{1}$ Initially associated with Igor Smirnov's regime, Sheriff was the only real political opposition to him in later years. In addition, the Polish Mint produced coins for Transnistria, which led to a diplomatic conflict between Poland and Moldova. The Mint (with a 42-percent stake held by the State Treasury) treated coins as commercial tokens, minted on commercial terms, at the order of a private entity. In 2005, the Mint withdrew from cooperation with Transnistria.

2 Areas of Polish-Moldovan cooperation: Nov. 15, 1994, Warsaw - Transfer and reception of persons residing without a permit (entered into force on May 28, 1995); Nov. 16, 1994, Warsaw - Mutual support and protection of investments (Jul. 27, 1995); Nov. 16, 1994, Warsaw Avoidance of double taxation, prevention of tax evasion in the area of income and property tax (Oct. 27, 1995); Jul. 27, 1995, Warsaw - Civil aviation (Mar. 18, 1997); Dec. 10, 1997, Warsaw Cultural and scientific cooperation (Feb. 1, 1999); Dec. 10, 1997, Chisinau - International road transport (Mar. 24, 1999); Oct. 27, 1998, Warsaw - Interregional cooperation (Jan. 13, 2000); Oct. 27, 1998, Warsaw - Military cooperation (Dec. 23, 2004); Sept. 18, 2002, Warsaw - Mutual assistance in customs-related matters (Aug. 8, 2004); Oct. 22, 2003, Chisinau - Fight against organized crime (Jul. 26, 2004); Oct. 22, 2003 - Environmental protection and management of natural resources (Feb. 10, 2004). 
an Union. The possibilities for Moldova to act in international relations increased, which was helpful in promoting the country's pro-European aspirations (Goworko-Składanek, 2015, p. 238; Kosienkowski, 2012, pp. 93-99) ${ }^{3}$ and which was reflected in the aid programme for developing countries launched in 2004. The resources were earmarked, among others, for the development of Moldova's agriculture and rural areas, which is what this article will be devoted to (Kodłubański, 2017; Tak się przemyca..., 2016) ${ }^{4}$. The political-theory background to the investments referred to in the Policy Coherence for Development (PCD), the European Union's Policy Coherence for Development (EU PCD) and Polish Official Development Assistance (ODA). The analyses presented in this article use the quantitative and qualitative research method, although due to the vastness of the issues addressed, only selected research results are presented. The quantitative and qualitative data refer to agricultural projects implemented in Moldova within the frames of and with the participation of the so-called Polish aid and development cooperation. The present study should be extended with further analyses defining problematic (not only sectoral) areas of support, but also with much more detailed quantitative data; however, these are materials for a separate study at present.

3 Areas of Polish-Moldovan cooperation after 2004: 2005 - Establishment of the European Union Border Assistance Mission to Moldova and Ukraine (EUBAM); Sept. 7, 2006, Krynica - Economic Cooperation (entry into force: May 24, 2007); June 4, 2007, Chisinau - Granting of a tied-aid loan (Aug. 14, 2007); 2008 - Polish-Swedish Eastern Partnership Initiative (approved by the EU in 2009); 2008 - Establishment of the Polish-Moldovan Forum for European Integration; 2009 - Poland joins the Group of Friends of Moldova established on the initiative of Romania; Feb. 18, 2010 - Granting of a loan of USD 15 million (Apr. 29, 2010); 2010 - Polish-Moldovan Forum for European Integration; 2011 - Donald Tusk in Moldova; 2011 - Parliamentary Assembly of Poland and Moldova; Sept. 13, 2011, Baku - Cooperation in healthcare and medical science (Dec. 27, 2011); 2012 - Inauguration of EU negotiations with Moldova on DCFTA; Dec. 3, 2012, Chisinau - Implementation Program for Culture, Education and Science 2012-2014 (Dec. 3, 2012); Sept. 9, 2013, Warsaw - Social Security (Dec. 1, 2014); Mar. 28, 2014, Chisinau Cooperation in the area of tourism (Aug. 1, 2014); May 14, 2014, Warsaw - Granting of a tied aid loan (Aug. 8, 2014).

4 The establishment of the Alliance for European Integration coalition in Moldova in 2009 has helped to strengthen cooperation between the countries. Also the subsequent embargoes imposed by Russia on Polish products (including apples in 2014) initiated a number of Polish-Moldovan trade contacts, possible thanks to the favour of the authorities in both countries. Also thanks to the support of Moldova, Ukraine, Belarus, Serbia and Lithuania, the export of Polish apples to Russia exceeded 1.1 million tonnes in 2015. Moldova's re-export was possible thanks to phytosanitary certificates from Vilnius. The signing of the EU association agreement with Moldova coincided with the introduction of a Russian embargo on apples from this country as well. 


\section{Policy Coherence for Development (PCD), European Union's Policy Coherence for Development (EU PCD) and Polish Official Development Assistance (ODA)}

Policy Coherence for Development (PCD) is an initiative supported by the Organization for Economic Cooperation and Development (OECD) countries (Policy Coherence..., n.d.) to exploit synergies between different areas, including trade, agriculture, health, environment, migration and development cooperation to achieve sustainable development. The idea is to stimulate development between developed and developing countries with a view to initiating specific economic, social, environmental, legal or political interactions. PCD also aims to establish instrumental mechanisms and instructions that will ensure effective, sustainable and coherent national policies in different sectors, analytical and monitoring mechanisms, and will support multi-stakeholder dialogue (MSD) (Dodds \& Benson, 2019). In 2012, the OECD identified the following areas as priorities: global food security, illegal financial flows, and the green economy, among others.

The European Union is also working on a common development policy (Polska pomoc - Portal Gov.pl, 2018). The coherent Community Policy in this area - the EU PCD - will be important here. The anchoring of PCD in the EU is strong and is based on the Treaty of Lisbon (Article 208). The Council Conclusions on Policy Coherence for Development of November 17, 2009 define five priority areas: trade and finance, climate change, food security, migration, and security. Every two years, the European Commission presents a report on Policy Coherence for Development to the EU Council, which draws its conclusions on the basis of this report. The current Conclusions on Policy Coherence for Development were adopted on October 26, 2015 (Council Conclusions..., 2019). On May 2, 2016, the European Parliament adopted the Report on the EU 2015 Report on Policy Coherence for Development (2016). The report contains recommendations on implementing the PCD principle in the context of Agenda 2030 and the Sustainable Development Goals (Polska pomoc - Portal Gov.pl, 2019; The Framework for Policy Coherence..., 2016). Policy Coherence for Development is also increasingly linked to the concept of development beyond aid, i.e., political, economic and social progress in a less developed country, which is the result of multiple factors and processes, and not only streams of aid flowing from the donor (Bagiński, 2012). The effects of these activities can be verified by means of the Commitment to Development Index (CDI) (The Commitment..., 2019).

Practical implementation of the concept of PCD is undertaken by various EU Member States. Poland implements it in the form of Polish Official Development 
Assistance (ODA). Poland is one of the few OECD (and EU) countries with a statutory obligation to implement PCD (Development Cooperation Act, 2011). The adoption of the Development Cooperation Act by the Polish Sejm in 2011 made it possible to formally start a mechanism of promoting Policy Coherence for Development in Poland. According to the legislation adopted, the Programme Council for Development Cooperation was established as well (Bagiński, 2019). Official Development Assistance in Poland is provided on the basis of the above act, dated September 16, 2011 (Development Cooperation Act, 2011). All matters related to development aid and humanitarian aid are handled by the Department of Development Cooperation (DDC) of the Ministry of Foreign Affairs (Polska pomoc-Portal Gov.pl, 2019). The activity of the Polish Embassy in Chisinau is invaluable in this context, especially the efforts and initiatives undertaken by the Polish Ambassador, Dr. Bartłomiej Zdaniuk. Considering the history of Polish diplomacy in Moldova after 1991, Ambassador Zdaniuk is one of the most active and creative Polish diplomats in Moldova (Zdaniuk, n.d.; Polska w Republice Motdawii, n.d.). The Information Centre for Local Authorities in Ialoveni (Solidarity Fund PL in Moldova, 2019), one of the flagship initiatives of the Polish government in Eastern Europe, should also be mentioned here (for more information, see below). All these institutions provide support within the framework of the so-called Polish Aid (Ministry of Foreign Affairs 1, 2019), which consists of four elements: development aid, humanitarian aid, development cooperation, and global education. As this article is focused on agricultural investments, most attention will be paid to the issues of development aid and cooperation for development. During its political and economic transformation, Poland benefited from the support of other political entities, including states, institutions, and international organizations. Currently, as a member of the European Union and the OECD Development Assistance Committee, Poland has itself become a donor of development aid. The main instrument for cooperation in this area is the Polish Aid Programme coordinated by the DDC of the Ministry of Foreign Affairs, as mentioned above. This is because Poland, along with other UN countries, has declared joint actions aimed at ensuring a real improvement of living conditions for people in developing countries (Polska pomocPortal Gov.pl, 2019) 5 .

5 The Millennium Development Goals were formulated at the UN in 2000. As early as 2002, Poland signed the Millennium Declaration and the Political Declaration and Action Plan, thus committing itself to participate in the undertakings of the international community aimed at solving global economic, social and humanitarian problems. In October 2003, the Polish Council of Ministers adopted the Polish Development Cooperation Strategy, which tidied up the system of Polish development cooperation in view of the upcoming membership in the European Union. Since joining 
By identifying areas of priority importance, objectives were formulated, within which future aid of European donors for Moldova should be focused on. These were included in the European Joint Development Cooperation Strategy (Joint Programming Document) for the Republic of Moldova (2018). This document is in line with the National Development Strategy of Moldova "Moldova 2020" (2012) and Moldova 2030 (2019). All these documents prioritize issues related to sustainable economic development, including agricultural politics and the agricultural industry. Support for the Republic of Moldova must be in line with the European Joint Development Cooperation Strategy (Ministry of Foreign Affairs 6, 2019).

By the end of 2018, as part of the Polish aid for Moldova, several hundred joint Polish-Moldovan projects were successfully implemented, with about two hundred initiatives from 2008 to 2017, whose value exceeded 233 million Moldovan lei. These funds were supplemented by international, European ${ }^{6}$ and American donors, of which there are currently more than 40 . The largest donor to Moldova is the European Union, which by the end of 2017 provided the Republic with more than one billion euro (Financial Transparency System, n.d.). This makes Moldova the largest beneficiary of the European Neighborhood and Eastern Partnership Policy. The second largest donor in Moldova after the European Union is the United States (Department of Development Cooperation, 2019). Moreover, interest of international donors in Moldova is gradually growing. They provide both non-returnable aid and preferential loans on very low interest.

the EU in 2004, Poland has paid contributions to the EU budget, from which Community development aid initiatives, supervised by the European Commission, are financed. Poland has committed itself to contribute to the financing of the European Development Fund, starting from its $10^{\text {th }}$ edition, which covered the period from 2008 to 2013. Another commitment made by Poland was signing of the Paris Declaration on Aid Effectiveness in March 2005. In August 2005, the Development Cooperation Department was established within the Ministry of Foreign Affairs, which has since been responsible for the national system of providing development aid. In December 2005, a new EU development policy strategy was adopted - the European Consensus on Development. A key moment in building of the Polish development aid system was the enactment of the Development Cooperation Act. According to it, Polish development cooperation is based on the Multi-annual Development Cooperation Program. The first multi-annual program covered the years 2012 to 2015 . On October 22, 2013, Poland became a member of the Development Assistance Committee (DAC) of the OECD - one of the key institutions responsible for creating modern standards of development cooperation. The second multi-annual program of Polish development cooperation - covering the years 2016 to 2020, containing a strategy of actions for developing countries, was adopted by the Polish Council of Ministers on October 6, 2015.

${ }^{6}$ It is important to note the support program of Sustainable Agriculture and Rural Development (SARD) - an annual European Union initiative implemented by the UNDP (United Nations Development Programme) in the Republic of Moldova. 


\section{Polish Development Aid for Moldova and LEADER Moldova}

Since 2004, Moldova has been on the list of priority recipients of Polish development aid, which is the result of international solidarity activities. It is one of four Eastern Partnership countries with which Poland has cooperated so closely.

Polish development aid in the form of grants is dominated by non-governmental organizations (NGOs). They implement most of the projects awarded in open competitions. Projects are implemented by various types of entities, both experienced ones, and ones that are of a more local character. The functioning of project providers is based on two models. The first of these provides for maintaining a permanent presence. Then such an organization registers on the territory of the country where it conducts development-related activities and implements projects using its own human and financial resources. In some cases, these organizations use financial resources from international institutions, which is an important source of support. Keeping a permanent presence makes it possible to react on an ongoing basis to changing local circumstances and emerging problems. An example of an institution operating according to the first model is the Polish Centre for International Cooperation Foundation (Polskie Centrum Pomocy Międzynarodowej, n.d.). The other model of operation is implementation of projects through a network of local partners who have local contacts and knowledge of the location-specific realities. In such a case, the project provider is left with only the supervisory function over the implementation of a grant (Ministry of Foreign Affairs 2, 2019, pp. 61-62).

NGOs are selected in an annual competition, which obviously has its advantages and disadvantages. There are plans to increase the effectiveness of providing development aid by, for example, commissioning the execution of tasks by means of public procurement (tenders), which would make it possible to impose specific requirements regarding the purpose, course and planned results, along with the requisite institutional and personal experience of the contractor(s). Based on the activities and experience of the European donors, a tendency to establish long-term cooperation with the most experienced and proven actors can be observed. These are the so-called framework entities, which become the operators of the funds, provide their own contribution to the implemented investments and can operate on the basis of regranting (Ministry of Foreign Affairs 2, 2019, p. 63). Undoubtedly, experience in implementing international projects and knowledge of the specificity of the region are the most important features of future entities implementing the projects.

A great success of Polish development cooperation in Moldova is the Information Centre for Local Authorities in Ialoveni. This project is one of three flagship 
initiatives, and the entity responsible for running the Centre is the International Solidarity Foundation (ISF). The main task of the Centre is to support local development. The Centre's activities are financed with development cooperation funds and receive support from international donors as well (these include EuropeAid, USAID, British AID, International Visegrad Fund, Lithuanian MFA and others). Local central authorities, local governments, NGOs, local entrepreneurs, foreign donors, Polish entities (NGOs, local governments, and the Ministry of Investment and Development) are all partners of the Delegation of the International Solidarity Foundation in Moldova (Ministry of Foreign Affairs 2, 2019, p. 69). The Centre is a good example of cooperation between different institutions at different levels: central authorities, local governments, NGOs, local entrepreneurs, foreign institutions (e.g., UNDP, or the Czech organization People in Need) (Ministry of Foreign Affairs 2, 2019, p. 75).

In rural areas, the Centre implements the EU LEADER/CLLD systemic approach to development (European Network for Rural Development, n.d.) ${ }^{7}$, which consists in setting up Local Action Groups in Moldova. The institution also supports the development of Local Development Strategies, and it finances pilot development initiatives under the Small Project Programme. Since 2012, the Centre has carried out training sessions and conferences, study visits, and established partnerships. In 2015, the Centre's initiatives were extended by a grant programme and assistance in writing strategic documents. The institution is gradually developing, implementing both interventions and process activities. In 2016, a systemic approach was introduced, i.e., broadly defined cooperation on the local and central level, based on pilot and implementation activities. Works related to a given context of intervention are based on the following initiatives: LEADER (targeting rural areas), revitalization (targeting urban areas), and Zaufanie dwóch brzegów [Trust between Two River Banks] (the separatist area of Transnistria) (Information Centre for Local Authorities in Ialoveni 2, n.d.).

${ }^{7}$ Innovation is a cross-sectional priority of the EU rural development policy and its link to the LEADER/CLLD approach is strengthened by the commitment of Local Action Groups (LAGs) to take innovation into account in planning Local Development Strategies (LDS). While EU regulations firmly embed aspects of innovation in the context of local development, the relevant European Commission guidelines provide detailed information on its practical implementation. 
Figure 1. Local Action Groups in Moldova in Rural Areas

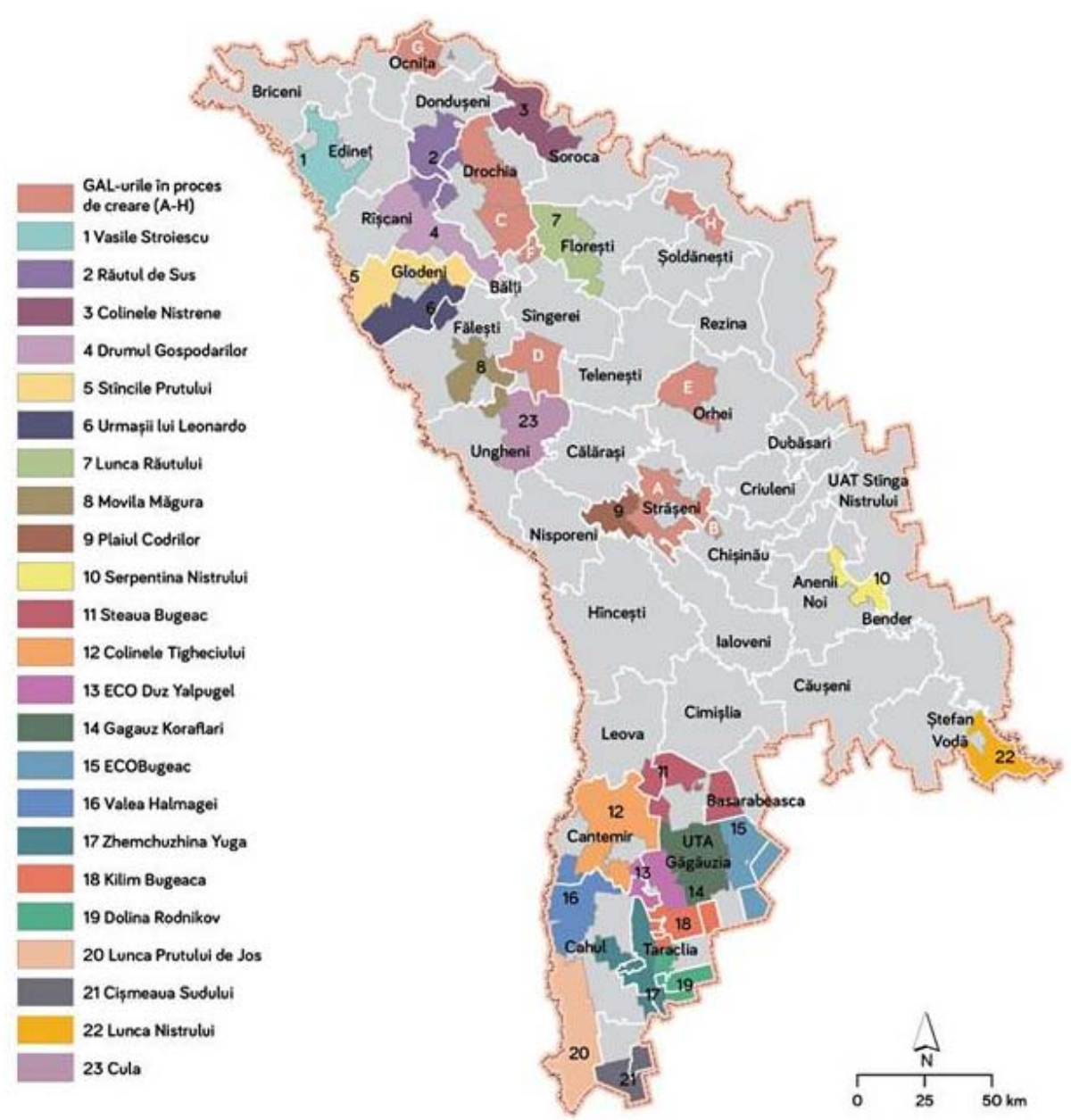

Source: Information Centre for Local Authorities in Ialoveni 1 (Retrospective - Internal Materials of the Centre, unpublished). Also: LEADER in Moldova [Facebook profile] (2018).

LEADER is the European Union's rural development instrument emphasizing economic development based on local resources. It helps to rediscover the potential of villages. The LEADER approach has been implemented for more than 25 years, both in the EU and in neighboring countries. In Moldova, there are three pillars for implementing the LEADER approach: 1 . Territory - LEADER is implemented 
in a specific area consisting of several or more neighboring localities, 2. Local Action Group - under the programme, an institutionalized partnership of representatives of local governments and public institutions, social partners, entrepreneurs and active residents is established, which animates development processes, 3. Local Development Strategy - a document is drawn up defining a common vision, development directions and specific measures and investments that the Local Action Group wants to implement in its area of operation (Information Centre for Local Authorities in Ialoveni 2, n.d.).

Figure 2. Areas of Activity of the Information Centre for Local Authorities in Ialoveni

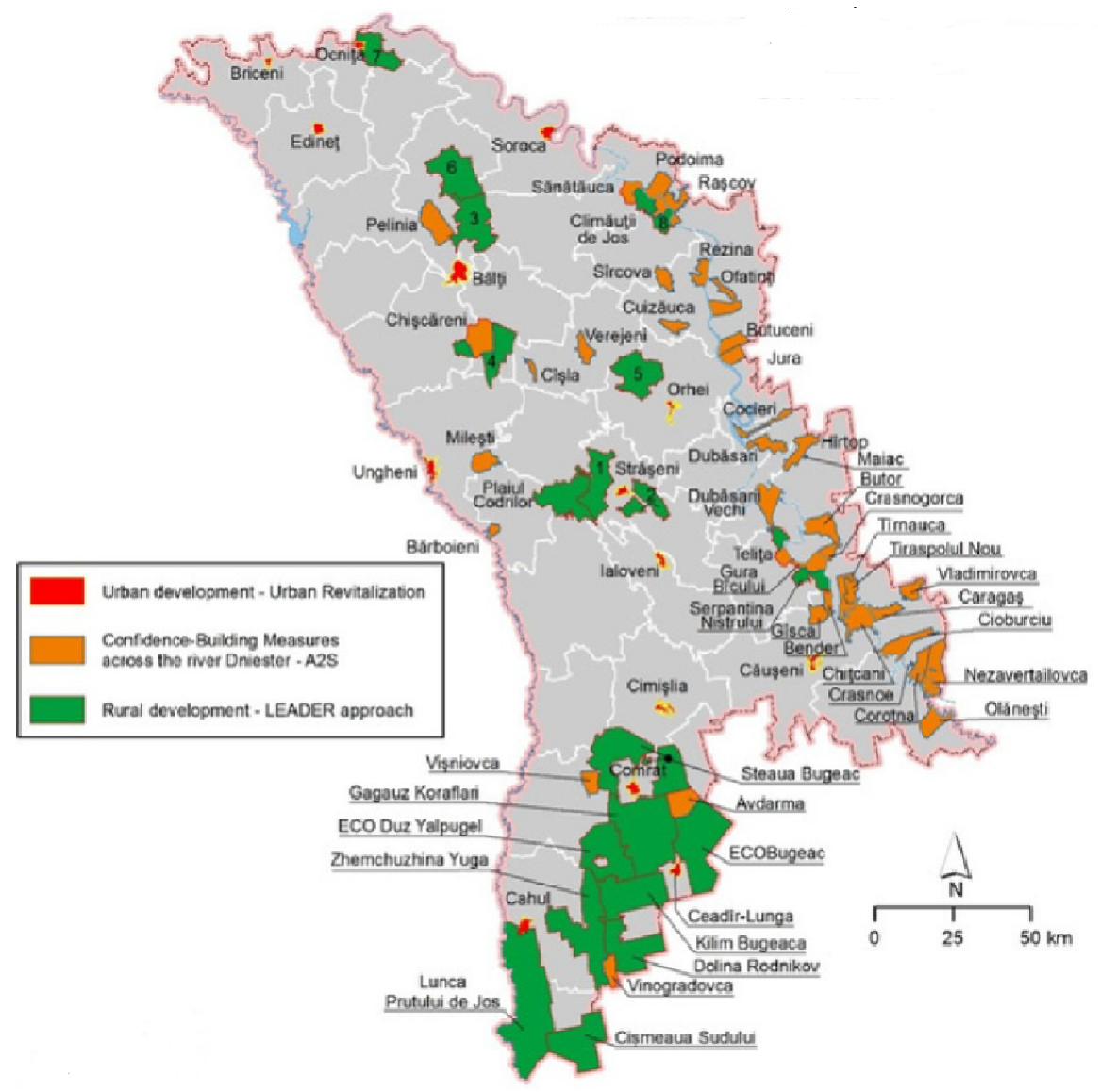

Source: Information Centre for Local Authorities in Ialoveni 1 (Retrospective - Internal Materials of the Centre, unpublished). 
LEADER in the Republic of Moldova is implemented in three steps. Firstly, the Information Centre for Local Authorities in Ialoveni helps to create Local Action Groups (LAG), helping to develop a common vision of development, a common action plan and a common cooperation experience. Secondly, the Centre helps to initiate activities of LAGs using such tools as local grant competitions, local project financing decisions, or local development projects. Thirdly, the Centre supports the development of LAGs and seeks to consolidate their operation in a given territory. The employees of the Information Centre for Local Authorities in Ialoveni provide content-related support to LAGs so that they may further animate local development processes, disburse development funds or create local development instruments. The measures in question are implemented jointly with the Ministry of Agriculture, Regional Development and Construction of Moldova, UNDP-Moldova and partners who work to implement the LEADER approach in Moldova: ProCoRe, People in Need-Moldova, and CONTACT-Cahul. These activities are financed with Polish aid, as well as USAID and EuropeAid (Information Centre for Local Authorities in Ialoveni 2, n.d.).

We need to add that in the current programming period (2014-2020) the LEADER method has been extended to not only rural but also coastal (FARNET) and urban areas under the motto of community-led local development (CLLD). All this makes LEADER an ideal tool for responding to the challenges facing Moldova on the local level on the road to transformation and modernization. The experience of other countries which implemented the LEADER mechanism shows that it can be used as an accelerator and stimulator of real change at the local level, both in terms of local development and in terms of community reinforcement and civic involvement (Solidarity Fund PL in Moldova, 2019).

The LEADER initiative in Moldova is based on Local Action Groups operating in rural areas. These will include Vasile Stroiescu, Răutul de Sus, Colinele Nistrene, Drumul Gospodarilor, Stîncile Prutului, Urmaşii lui Leonardo, Lunca Răutului, Movila Măgura, Plaiul Codrilor, Serpantina Nistrului, Steaua Bugeac, Colinele Tigheciului, ECO Duz Yalpugel, Gagauz Koraflari, ECO Bugeac, Valea Halmagei, Zhemchuzhina Yuga, Kilim Bugeaca, Rodnikov Valley, Lunca Prutului de Jos, Cişmeaua Sudului, Lunca Nistrului, Cula (for details, see Figure 1) (Leader Reloaded Conference, 2018; Towards Prospering Rural Areas..., n.d.).

In 2018, the following result indicators were developed thanks to the activities of the Ialoveni Information Centre for Local Authorities: 11 opened and operating Local Action Groups, 8 LAGs in the process of creation, 160 local development projects financed by the LAGs, 150 rural towns covered by LEADER measures, $20 \%$ of the rural population involved in LEADER activities. 
The activities of the Information Centre for Local Authorities in Ialoveni also include projects related to urban revitalization, as well as the initiative entitled $Z a$ ufanie dwóch brzegów [Trust between Two River Banks], under which measures integrating the population on both sides of the Dniester River are implemented. The development indicators achieved in urban regeneration comprise 10 implemented pilot projects, 10 Local Revitalization Programmes, construction of the Urban Revitalization Network or 250,000 inhabitants of cities covered by revitalization measures. In turn, 42 localities were involved in the Zaufanie dwóch brzegów initiative. In addition: 21 partnerships between entities on the two sides of the river were created, 42 Local Strategic Plans were developed, and 17 projects integrating people on both sides of the Dniester River were implemented. More than 1,500 Moldovan local leaders were involved in the activities initiated by the Information Centre for Local Authorities in Ialoveni (the details are presented in Figure 2).

There are numerous examples of the impact of the LEADER programme in Moldova, including support to beekeepers from the villages of Dolna and Stejăreni și Micleușeni (Solidarity Fund PL in Moldova, 2019), a plum-drying oven for the Necula family (Solidarity Fund PL in Moldova, 2019), creation of conditions for fruit processing in the Galilor Plaiul Codrilor microregion, creation of a tourist area in Hajarja, improvement of vegetable packaging technology in Plaiul Codrilor, projects supporting crafts and handicrafts in Lunca Prutului de Jos (Solidarity Fund PL in Moldova, 2019), modernization of the Dumitru Zaporojana home workshop, revitalization of the village park in Primăria Slobozia Mare, and purchase of equipment necessary for the Casa Dulce confectionery (Information Centre for Local Authorities in Ialoveni 2, n.d.), owned by Ana Cucu. It may be surprising to see such a bottom-up focus of support, but it should be remembered that in Moldova farms are single units, mostly family-owned and fragmented (about 1.5 ha). The large fragmentation necessitates cooperation in joint organization of services and in using of agricultural equipment. It is also necessary to cooperate with respect to storage, processing, packaging and distribution (Department of Development Cooperation, 2019). Hence the strong need for producer initiatives and cooperatives bringing together different partners within the agricultural sector.

\section{Agriculture and Rural Development as Priorities of Polish Development Cooperation for Moldova}

Polish development cooperation implemented in Moldova focuses primarily on supporting good governance, agriculture, and rural development. As indicated by 
the Polish Ministry of Foreign Affairs, projects in these areas fit into the assumptions of the European Common Strategy (Ministry of Foreign Affairs 5, 2019). Three areas of intervention are important here; the first of these covers economic development and market opportunities, including sustainable economic growth conducive to social inclusion, social welfare and health, the second one - institutional strengthening and good governance, including the rule of law and security (Ministry of Foreign Affairs 6, 2019). Stimulating economic growth in rural areas should take place along two main paths.

In view of the issue in question, the first priority will be the most important one. It includes the following directions of support: business environment and trade, rural poverty and regional disparities, agriculture, food security and rural development, along with social protection and health. Poland implements projects in Moldova concerning the development of the agricultural sector, covering mainly measures leading to increasing the productivity and competitiveness of agricultural holdings and agricultural consultancy (purchase of machinery, construction of farm buildings, creation of model forms of providing various agricultural services). Projects are also implemented in non-agricultural services (mainly tourism and agritourism), responding to the demand for measures aimed at improving living conditions in rural areas. The Central Statistical Office in Poland supports the Department of Agriculture and Environment of the National Statistical Office of Moldova in the area of statistical research in agriculture, agricultural policy, and forestry (Ministry of Foreign Affairs 2, 2019, pp. 60-61).

What seems important is to strengthen both the sources of income of farms and the already mentioned non-agricultural activities, as well as to improve access to infrastructure and services in rural areas. The need to implement such projects results from the needs of the Moldovan agricultural sector, as one of the main pillars of the country's economy, which requires far-reaching technological, structural and organizational modernization. Support is also required for measures concerning the creation of conditions for employment outside the agricultural sector (Ministry of Foreign Affairs 2, 2019, p. 66). Within the framework of projects implemented mainly through NGOs (e.g., the "East" Foundation, and the Prince Konstanty Ostrogski Foundation), activities consisting in the purchase of agricultural equipment, development of agricultural services and agricultural consultancy are carried out. Support is provided to projects concerning the development of non-agricultural activities - service, production, as well as tourism and agritourism. Its main objective is to create new jobs and reduce economic emigration from rural areas in Moldova. The main implementer of such activities is the Development Policy Foundation (Ministry of Foreign Affairs 2, 2019, pp. 67-68). 
A number of projects have been implemented in the agricultural and rural development sector, such as development of milk production in the region of Ignatei, completion of gasification of the southern part of the Brynza village, renovation of the heating system in the kindergarten in the village of Kirjet-Lunga, renovation of the sewage system in the school in the village of Popenki, improvement of conditions for children in the kindergarten in the village of Nucăreni, reconstruction of sanitary facilities in the kindergarten in the village of Suri (region of Drochia), renovation of the ecological well in Raşcov, modernization of the junior high school in the village of Mileștii, construction of a sanitary sewerage system in the village of Rîșcani, registration and promotion of local and regional products in the region of Câlârași, expanding the potential of farms in the region of Ungheni through the introduction of additional sources of income and forming associations of village residents (Polska pomoc - Portal Gov.pl, 2019).

Investments have been made in an innovative network for the development of entrepreneurship and cooperation, agricultural cooperatives, agricultural advisory services and producer groups, Moldovan culinary trails, innovative ecological technologies and techniques for the development of sustainable agriculture in Moldova, ecological water treatment plants, "green economy" in the development of agriculture in Moldova, alternative energy sources and innovative energy-saving technologies in the development of Moldovan villages, agritourism (as a form of investment), technical and technological innovations (including renewable energy sources) on farms (Ministry of Foreign Affairs 3, 2013, p. 34), in the modernization of beekeeping in Moldova, and in improving competences and qualifications of Moldovan sugar beet growers. Support has also been provided to the Moldovan veterinary services, to help them implement sanitary and veterinary requirements and improve sanitary controls under the food safety policy. Much attention has been paid to preparing Moldovan local communities for effective absorption of European funds and preparing Moldovan agricultural advisory services for activities preceding accession to the European Union (Ministry of Foreign Affairs 3, 2013, p. 34).

These are obviously only a few examples of Polish cooperation and development aid activities in agriculture and rural development in Moldova. The potential for cooperation between Poland and Moldova in the areas of agriculture and rural development is really vast. 


\section{Summary}

The economy of Moldova is based on low-processed agricultural products and thirty percent of the country's population works in the agricultural sector (Całus, 2019). This area requires a number of reforms, which, if properly implemented, will contribute to an increase in the standard of living of the region's residents. It is also important to coordinate sustainable development of rural areas in the centre of the country with support for regional development (Development Assistance Department). The Polish-Moldovan cooperation initiated in relation to Polish aid and development strongly supports Moldovan agriculture (Motdawia..., 2016) ${ }^{8}$, bringing many benefits for both Moldova and Poland as the donor country (Ministry of Foreign Affairs 2, 2019, p. 61) $)^{9}$.

Poland has "discovered Moldova for itself" (Kosienkowski, 2012, p. 100), initiating a series of investment contacts and Polish-Moldovan economic relations, and making agriculture one of the most promising sectors of the cooperation between Poland and Moldova (Goworko-Składanek, 2015, p. 243). In this respect, all initiatives should be developed which further the implementation of particularly relevant contextual indicators in Moldova (Ministry of Foreign Affairs 4, 2018, pp. 1-51), including support given to farms, newly established groups of producers, associations and agricultural cooperatives, innovations and improvements in production and sales, transfer and installation of equipment, acquisition of new skills and competencies in improving the competitiveness of Moldovan farms, support given to individuals who may benefit from vocational guidance, establishment of enterprises, including sole-proprietorship businesses, as well as adoption of new tools and technologies by enterprises.

8 On August 8, 2014, the Government Tied Assistance Credit Agreement for the Republic of Moldova entered into force as an instrument of official support given to export. Under the Agreement, the Government of Poland committed to grant the Government of the Republic of Moldova with a preferential credit facility of up to $€ 100$ million destined to finance the export of goods and services from Poland to Moldova in the area of agriculture and food processing, including related infrastructure.

${ }^{9}$ An interesting issue for future cooperation is the subject of energy security, energy efficiency and diversification of energy sources, including RES. A potential new direction of support for Moldova could also be the environmental area, especially water and sewage issues. 


\section{References:}

Bagiński, P. (2012, May). Spójność polityki na rzecz rozwoju a polska polityka wschodnia. Warszawa: Fundacja Batorego.

Goworko-Składanek, B. (2015). Wybrane aspekty współpracy polsko-mołdawskiej w latach 2010-2014. Studia Podlaskie, 23, 237-254. DOI: 10.15290/sp.2015.23.11.

Kosienkowski, M. (2012). Polska a Mołdawia i Naddniestrze. Rocznik Instytutu Europy Środkowo-Wschodniej, 10(1), 91-106.

Wróbel, J. (2012). Przestępczość gospodarcza w Naddniestrzu. Przegląd Bezpieczeństwa Wewnętrznego, 4(7), 31-48.

\section{Unpublished materials:}

Information Centre for Local Authorities in Ialoveni 1 (n.d.). Retrospektywa. Materiały wewnętrzne Centrum Informacyjnego dla Władz Lokalnych w Ialoveni.

Information Centre for Local Authorities in Ialoveni 2 (n.d.). Materiał promujący działalność Centrum Informacyjnego dla Władz Lokalnych w Ialoveni.

\section{Internet Sources:}

Bagiński, P. (2019). Wdrażanie koncepcji spójności polityki na rzecz rozwoju do polskiej polityki zagranicznej. Doświadczenia europejskie, rekomendacje dla Polski. Retrieved from: http://www.batory.org.pl/upload/files/Programy\%20operacyjne/Otwarta\%20Europa/Wdrazanie_PCD_Doswiadczenia_europejskie.pdf.

Całus, K. (2019). Państwo niedokończone. 25 lat motdawskiej niepodlegtości. Prace OSW, 59. Warszawa: Ośrodek Studiów Wschodnich. Retrieved from: https://www.osw.waw. pl/sites/default/files/prace_59_pl_25_lat_moldawskiej_net.pdf.

The Commitment to Development Index 2018 (2019). Retrieved from: www.cgdev.org/ commitment-development-index-2018.

Council Conclusions on Policy Coherence for Development (PCD) (2019). 2015 EU Report. Retrieved from: https://www.consilium.europa.eu/pl/press/press-releases/2015/10/26/ fac-conclusions-pcd-2015-report/.

Department of Development Cooperation (2019). Propozycje dziatań projektowych $w$ Motdawii dla polskich podmiotów z zakresu rozwoju regionalnego i decentralizacji oraz zrównoważonego rozwoju obszarów wiejskich. Dokument pomocniczy do wieloletniego programu wspótpracy rozwojowej na lata 2012-2015. Warszawa: Ministerstwo Spraw Zagranicznych, Departament Współpracy Rozwojowej. Retrieved from: https://webcache.googleusercontent.com/search?q=cache:8efL8ACaK9YJ:https:/www. polskapomoc.gov.pl/download/files/Dokumenty_i_Publikacje/Propozycje\%2520dz ialan $\% 2520$ projektowych $\% 2520 \mathrm{w} \% 2520$ moldawii.pdf $+\& \mathrm{~cd}=1 \& \mathrm{hl}=\mathrm{pl} \& \mathrm{ct}=\mathrm{clnk} \& \mathrm{gl}$ $=$ pl\&client=firefox-b-ab.

Development Cooperation Act (2011). Ustawa z dnia 16 września 2011 roku o współpracy rozwojowej. JoL 2011 No. 234, item 1386. Retrieved from: http://orka.sejm.gov.pl/ opinie6.nsf/nazwa/4469_u/\$file/4469_u.pdf. 
Dodds, F., \& Benson, E. (2019). Multi-Stakeholder Dialogue. Retrieved from: https:// www.civicus.org/documents/toolkits/PGX_D_Multistakeholder\%20Dialogue.pdf.

European Joint Development Cooperation Strategy (Joint Programming Document) for the Republic of Moldova (2018, February 28). Retrieved from: www.eeas.europa.eu/delegations/moldova/40533/european-joint-development-cooperation-strategy-joint-programming-document-republic-moldova_en.

European Network for Rural Development (n.d.). Innowacje w ramach podejścia LEADER. Retrieved from: https://enrd.ec.europa.eu/leader-clld/leader-innovation_pl.

Financial Transparency System (n.d). Retrieved from: http://ec.europa.eu/budget/fts/index_en.htm.

The Framework for Policy Coherence for Sustainable Development (2016, May 4). Retrieved from: http://www.oecd.org/gov/pcsd/Framework_Generic\%20Module_PCD(2016)1. pdf.

Kodłubański, T. (2017, October 2). Embargo na jabtka nadal utrudnia „życie” polskim sadownikom. Retrieved from: www.agrofakt.pl/embargo-na-jablka-utrudnia-zycie-polskim-sadownikom/.

LEADER in Moldova [Facebook profile] (2018, November 15). Retrieved from: https:// www.facebook.com/leader.moldova/photos/a.2157203181267239/215847337780688 6/?type $=3 \&$ theater.

Leader Reloaded Conference (2018, September 26-28). SARD LEADER/CLLD 2014-2020 (conference materials). Retrieved from: https://leaderconference.minhaterra. pt/rwst/files/I100-MOLDOVAXREPUBLICXOF.PDF.

Ministry of Foreign Affairs 1 (2019). Wieloletni Program Wspótpracy Rozwojowej 2012-2015. Solidarność. Demokracja. Rozwój. Warszawa: Ministerstwo Spraw Zagranicznych. Retrieved from: https:/www.gov.pl/web/polskapomoc/archiwalne-wieloletnieprogramy-wspolpracy-rozwojowej.

Ministry of Foreign Affairs 2 (2019). Ewaluacja polskiej wspótpracy rozwojowej: Wieloletni program wspótpracy rozwojowej na lata 2016-2020, w potowie okresu realizacji. Raport końcowy. Warszawa: Ecorys dla Ministerstwa Spraw Zagranicznych. Retrieved from: http://webcache.googleusercontent.com/search?q=cache:GGp34DZieiYJ:polskapom oc.gov.pl/download/files/Ewaluacja/Raport_z_Ewaluacji_PL_2018.pdf+\&cd=1\&hl= pl\&ct=clnk\&gl=pl\&client=firefox-b.

Ministry of Foreign Affairs 3 (2013). Poland's Development Cooperation: Annual Report 2012 [Polska wspótpraca na rzecz rozwoju. Raport roczny 2012]. Warszawa: Ministerstwo Spraw Zagranicznych, Departament Współpracy Rozwojowej. Retrieved from: https://webcache.googleusercontent.com/search?q=cache:UFG3I5x1rb4J:https://www. gov.pl/web/polishaid/polands-development-cooperation-annual-report-2012+\&cd=2 $\& \mathrm{hl}=\mathrm{pl} \& \mathrm{ct}=\mathrm{clnk} \& \mathrm{gl}=\mathrm{pl} \& \mathrm{client}=$ firefox-b-d.

Ministry of Foreign Affairs 4 (2018). Plan wspótpracy rozwojowej w 2018 r. Warszawa: Ministerstwo Spraw Zagranicznych, Departament Współpracy Rozwojowej. Retrieved from: https://www.gov.pl/attachment/23f128f5-d816-4f50-9918-864cc5267131.

Ministry of Foreign Affairs 5 (2019). Wieloletni program wspótpracy rozwojowej na lata 2016-2020. Warszawa: Ministerstwo Spraw Zagranicznych. Retrieved from: https://www.pol- 
skapomoc.gov.pl/Wieloletni,program,wspolpracy,rozwojowej,na,lata,2016-2020,2080. html.

Ministry of Foreign Affairs 6 (2019). Ewaluacja polskiej wspótpracy rozwojowej: Wieloletni program wspótpracy rozwojowej na lata 2016-2020, w potowie okresu realizacji. Raport końcowy. Warszawa: Ecorys dla Ministerstwa Spraw Zagranicznych. Retrieved from: http://webcache.googleusercontent.com/search?q=cache:GGp34DZieiYJ:polskapom oc.gov.pl/download/files/Ewaluacja/Raport_z_Ewaluacji_PL_2018.pdf+\&cd=1\&hl= $\mathrm{pl} \& \mathrm{ct}=\mathrm{clnk} \& \mathrm{gl}=\mathrm{pl} \& \mathrm{client}=$ firefox-b.

Motdawia. Informacje o stosunkach gospodarczych z Polska (2016). Retrieved from: www. mpit.gov.pl/media/21638/KW_Moldavia_28_06_2016.pdf.

National Development Strategy "Moldova 2020": Seven Solutions for Economic Growth and Poverty Reduction (2012). Retrieved from: www.cancelaria.gov.md/en/apc/nationaldevelopment-strategy-moldova-2020-seven-solutions-economic-growth-and-povertyreduction.

National Development Strategy "Moldova 2030" (2019). Retrieved from: www.md.one. un.org/content/unct/moldova/en/home/presscenter/press-releases/strategia-na_ionalde-dezvoltare-moldova-2030--aprobat-de-guvern.html.

PCSD Partnership (n.d.). Retrieved from: https://community.oecd.org/community/pcsdpartnership/content.

Policy Coherence for Development (PCD) (n.d.). Retrieved from: http://www.oecd.org/development/policycoherence.

Polska pomoc - Portal Gov.pl (2018). O nas. Retrieved from: www.polskapomoc.gov.pl/ O,nas,906.html.

Polska pomoc - Portal Gov.pl (2019). Motdawia. Retrieved from: www.polskapomoc.gov. $\mathrm{pl} /$ Moldawia,16.html.

Polska w Republice Motdawii (n.d.). Ambasada RP w Kiszyniowie. Retrieved from: www. kiszyniow.msz.gov.pl/pl/ambasada/.

Polskie Centrum Pomocy Międzynarodowej (n.d.). Retrieved from: www.pcpm.org.pl/.

Report on the EU 2015 Report on Policy Coherence for Development (2015/2317(INI)) (2016,

May 2). Retrieved from: http://www.europarl.europa.eu/sides/getDoc.do?pubRef=-// $\mathrm{EP} / / \mathrm{TEXT}+\mathrm{REPORT}+\mathrm{A} 8-2016-0165+0+\mathrm{DOC}+\mathrm{XML}+\mathrm{V} 0 / / \mathrm{EN}$.

Solidarity Fund PL in Moldova (n.d.). Retrieved from: www.centruinfo.org/.

Tak się przemyca polskie jabtka do Rosji (2016, March 2). Retrieved from: www.kresy24.pl/ tak-sie-przemyca-polskie-jablka-do-rosji/.

Towards Prospering Rural Areas: The SARD LEADER/CLLD Initiative (n.d.). Retrieved from: www.leadermoldova.eu.

Zdaniuk, B. [@BZdaniuk] (n.d.). Twitter. Retrieved from: https://twitter.com/bzdaniuk. 